\title{
Investigation of clay sediments and bedrock morphology in caves with seismic traveltime tomography: an application at Alepotrypa Cave (Diros, Greece)
}

\author{
Lazaros Polymenakos \\ Consultant-Independent Researcher, Athens, Greece
}

\begin{abstract}
The deposition of unconsolidated clay sediments in caves, in relation to the buried morphology of the karstic conduit, are important parameters for the study of cave evolution. We introduce the application of an active seismic imaging technique to investigate the clay deposits and bedrock morphology in caves. Seismic traveltime tomography, applied for the first time in cave studies, can assist with the interpretation of cave geomorphology. Utilizing the P-wave velocity contrast between the clay sediments and the surrounding rock mass, we map the buried rock surface and significant sediment interfaces and provide an estimate of the sediment thickness and volume. Our study focuses on the Alepotrypa Cave located in Diros (Peloponnese, Greece), revealing important information for the evolution of the cave. The proposed technique could be applied in caves with significant clay deposits, in order to constrain the clay volume and reconstruct the buried floor shape of the cave. The technique exploits fully the ground morphology and access points in a cave, so it is suitable for a detailed three-dimensional exploration of cave deposits and the underlying cave morphology.
\end{abstract}

Keywords: $\quad$ seismic traveltime tomography, P-wave velocity, sediment thickness, bedrock surface, Alepotrypa Cave, Greece

Received 9 June 2016; Revised 1 November 2016; Accepted 3 November 2016

Citation: Polymenakos L., 2017. Investigation of clay sediments and bedrock morphology in caves with seismic traveltime tomography: an application at Alepotrypa Cave (Diros, Greece). International Journal of Speleology, 46 (1), 1-12. Tampa, FL (USA) ISSN 0392-6672 https://doi.org/10.5038/1827-806X.46.1.2005

\section{INTRODUCTION}

Sedimentary deposits in caves are important for the study of cave evolution and past environmental conditions related to human occupation. As a result, cave sediments have been the focus of many speleogenesis studies (e.g., Ford \& Ewers, 1978; Palmer, 2007; Farrant \& Smart, 2011). Cave deposits are primarily of clastic type (clays, terra rossa), followed by sediments of chemical or biological origin. Depending on the environmental and depositional conditions, the clay deposits may reach several meters in thickness (Perroux, 2005). These deposits cover the floor of caves, limiting speleogenesis studies to the observation of morphology on ceiling and cave walls, which cannot reveal the dynamics of the cave such as collapse phases or clay evacuation during cave evolution history.

A non-destructive means of studying the sedimentary geology of a cave would provide significant information otherwise inaccessible, while preserving the delicate environmental conditions of the cave. This paper proposes the use of an active geophysical imaging technique that can be applied for studying clay deposits and cave buried morphology complementing other methods of cave speleogenetic exploration.

Geophysical methods commonly used in exploration have potential application to geoenvironmental investigations in karstic terrains and caves (e.g., Chalikakis et al., 2011; Nehmé et al., 2013). Ground penetrating radar (GPR) and electrical resistivity tomography (ERT) can be used to trace caves (e.g., Chamberlain et al., 2000; Gibson et al., 2004; ElQady et al., 2005; Valois et al., 2010; Gosar \& Čeru, 2016), search for discontinuities in limestone rocks and determine soil depth in buried karst terrains (e.g., Zhou et al., 2000; Harvitch \& Valenta, 2011; Hamdan et al., 2012) and determine soil thickness in archaeological sites (see e.g., Griffiths \& Barker, 1994; Drahor et al., 2008), mines and caves (Kauffman, 2002). Seismic methods can be used for geological mapping and estimating the depth of soft cover layers (e.g., Ibs-Von Seht \& Wohlemberg, 1999; Polymenakos \& Papamarinopoulos, 2007; Coulouma et al., 2012; 
Giocoli et al., 2015) and for the detection of caves (e.g., Surányi et al., 2010). Considering the application of geophysical techniques inside a cave, GPR techniques can provide detailed information on cave sediment stratigraphy, however severe limitations can arise when applied on surficial wet clay layers of a cave, because of the strong signal attenuation in these types of soils (Jessop, 1995). The use of ERT inside caves is capable of providing information related to cave sediment stratigraphy, but its use is hindered due to limited layout deployment and edge effects that can dominate the electrical signals near cave walls (Kauffman, 2002; Nehmé et al., 2013). Passive seismological imaging (PSI; Nehmé et al., 2013) can overcome cave limitations on spatial and depth coverage, but it is subject to inherent limitations in horizontal and vertical resolution.

This paper proposes the use of seismic traveltime tomography as a technique suitable for cave imaging for several reasons: (i) it is a non-destructive procedure adapted to variant relief landscape that can be applied to all sizes of caves without the need for trenching or drilling; (ii) it is an active-source seismic technique that can overcome limits on efficiency and spatial coverage posed by the cave environment on other active-source techniques such as ERT or GPR, and passive-source techniques such as PSI; (iii) this seismic technique is extensively used to discriminate between geological materials that present a velocity contrast such as sediments lying over or in-between rocks, as in the case of clay sediments overlying limestone bedrock in a cave; (iv) the tomography technique provides the most robust, spatially continuous and detailed mapping of seismic wave velocities, in two or three dimensions at various scales, overcoming the limitations of velocity estimation by seismic refraction (Barton, 2007) with increased resolution (Polymenakos \& Tweeton, 2015). Typical applications of seismic traveltime tomography include mapping of empty or sediment filled fractures and soft or hard geological materials in underground mines and facilities (e.g., Jackson et al., 1995; AjoFranklin et al., 2013), and estimating the geometry and depth of cover sediments in landslides (e.g., Lanz et al., 1998; Samyn et al., 2012; Adamczyk et al., 2013) and archaeological sites (e.g., Witten et al., 1995; Polymenakos et al., 2004; Polymenakos \& Papamarinopoulos, 2005; 2007).

Seismic traveltime tomography is used to map clay thickness and bedrock morphology of Alepotrypa Cave. Use of other geophysical techniques for possible validation or complement of the tomography results was inefficient because of hindering local conditions (severe effects of the clay sediments on GPR signal attenuation; strong spatial limitations and surface obstructions on efficient ERT layout deployment and signal penetration). The results will improve observation of the bottom parts of the cave and provide information related to stages of speleogenesis.

\section{Cave description}

Alepotrypa Cave is located in Southern Mainland Greece, on the western shore of Mani Peninsula in Peloponnese (Fig. 1). It was discovered in 1958
(Petrocheilou, 1992). It is located $15 \mathrm{~m}$ above sea level, is $280 \mathrm{~m}$ long and has an elongated shape with numerous chambers and passageways. It can be divided in two main areas, the largest of which dimensions 130 × $50 \mathrm{~m}$ and has a lake of fresh water (Fig. 2). The cave is one of several karst formations which abound along the western Mani peninsula as a result of post-Miocene tectonic processes that greatly contributed to karstification and cave morphology (Bassiakos, 1993). Post-glacial environmental and geological conditions contributed to an accumulation of paleontological and paleoanthorpological finds in the caves and caverns of Mani area, usually within cohesive limestone breccia with terra-rossa as bond material (Giannopoulos, 2000). The cave contained a large Neolithic settlement with thick cultural levels and a continuous human occupation from 8000 BP until abandonment of the site around 5200 BP (Papathanassopoulos, 1996; 2011; Papathanasiou, 2001; Tomkins, 2009). A multidisciplinary research project has been conducted at the site by members of the Diros Project (Parkinson et al., 2016).

The cave is formed in Upper Cretaceous-Eocene semi-crystalline limestones of the Kriti-Mani (Plattenkalk) Unit (Bassiakos, 1993), a medium-tothick bedded, heavily jointed and karstified carbonate formation with an overall thickness of $300 \mathrm{~m}$. This rock formation is exposed at the walls and roof of the cave dome (Fig. 3a). The speleogenesis of Alepotrypa Cave is not studied in detail so far. However, the primary cause would have been chemical weathering of limestone with the assistance of fresh and brackish water circulation within the cave (a reminder of which is the lake at the eastern end of the cave) as suggested for the neighboring Glyfada Cave-lake (e.g., Giannopoulos, 2000). Rock joints and faults in the rock mass are considered to have greatly contributed to the directional development and shape of the numerous cave sub-areas: the directions of passageways in Alepotrypa Cave are consistent with the principal directions of rock joints in the area,

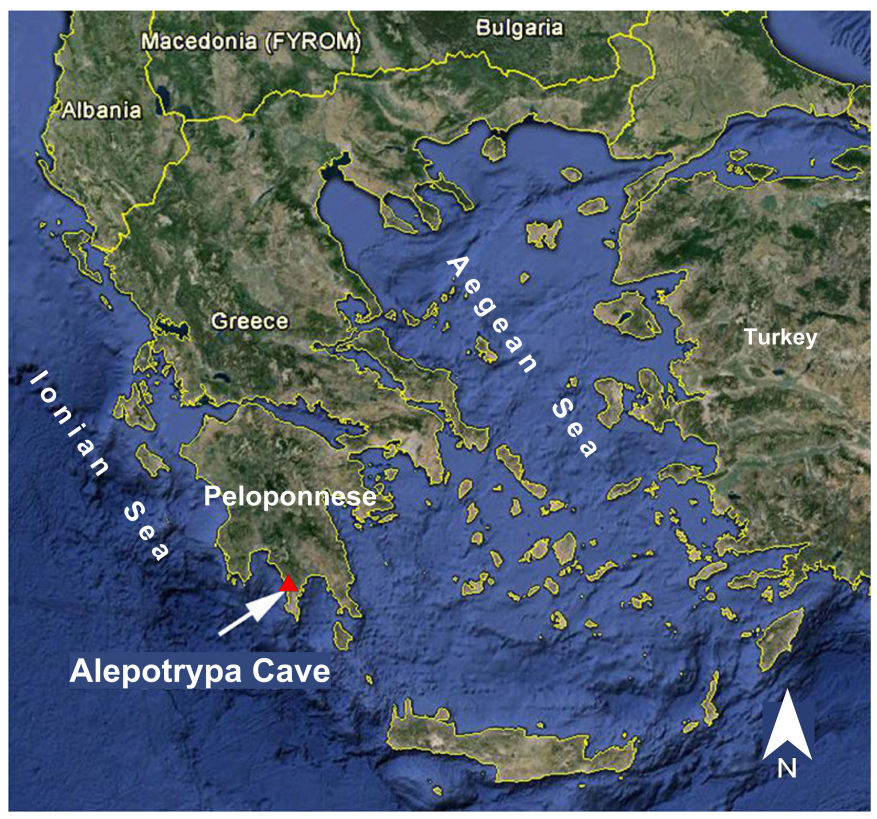

Fig. 1. The location of Alepotrypa Cave in Southern Mainland Greece (background image available from GoogleEarth; accessed: May 10, 2016). 


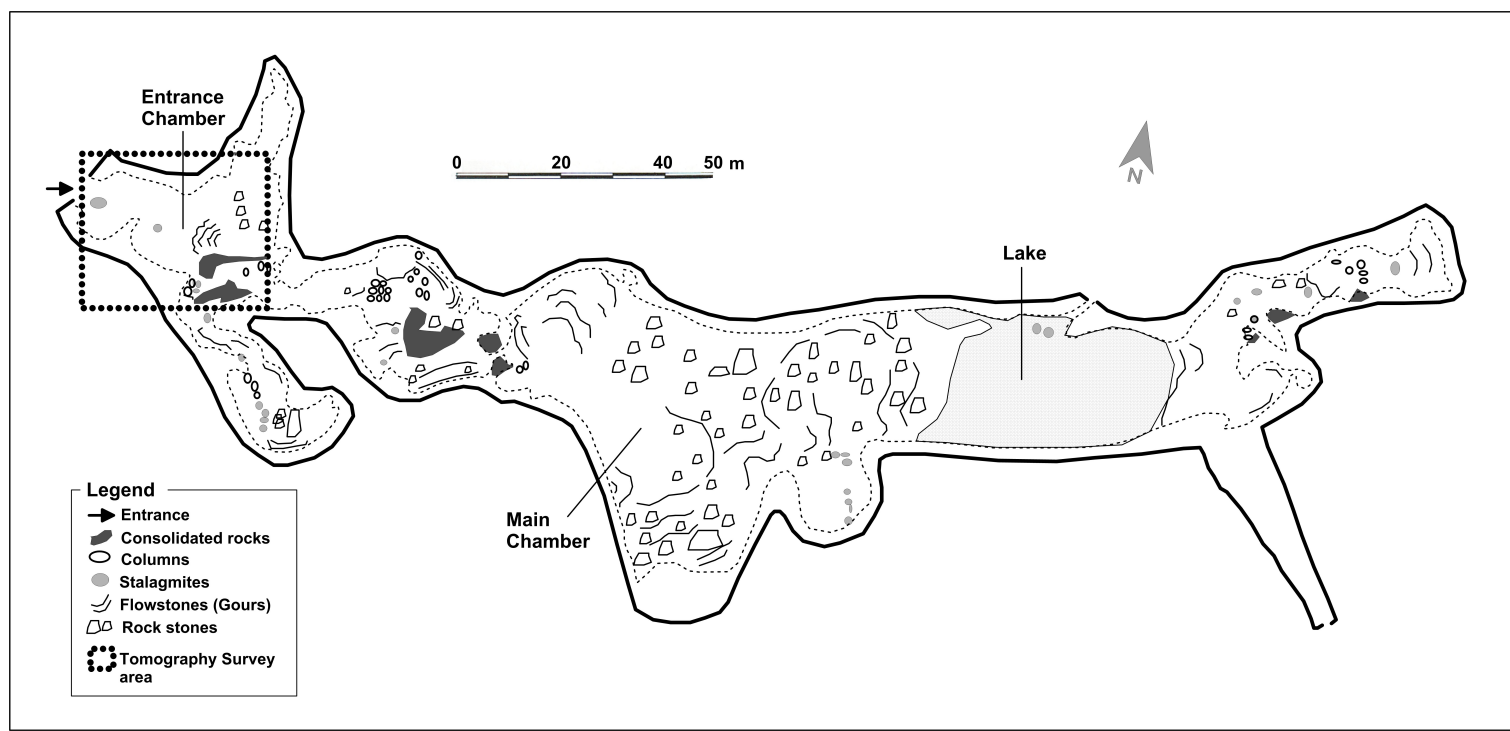

Fig. 2. Floor plan of Alepotrypa Cave (modified after Petrocheilou, 1992). The tomography survey area is shown at far left.
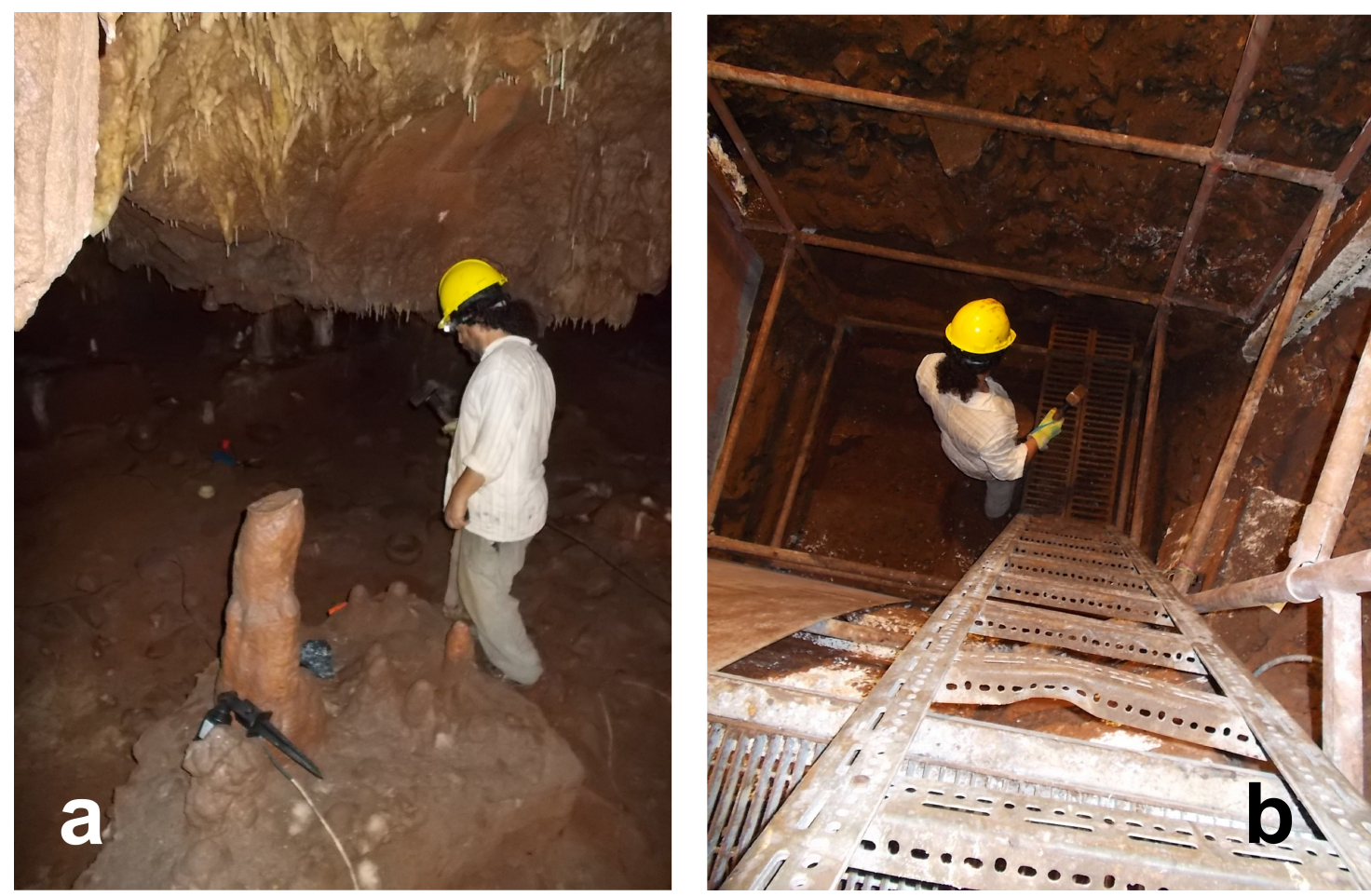

Fig. 3. a) Typical interior morphology of Alepotrypa Cave with rock walls, stalagmites and clay sediments; b) Clay/ash interval observed in an excavation pit (for location see Fig. 4). Photos taken by the author in July 2014.

NNW-SSE and E-W (Bassiakos, 1993; see also Fig. 2). The cave morphology would have also been affected by local alterations between crystalline limestone and limestone breccia, the latter appearing as a result of tectonic activity and being more susceptible to erosion. A recent factor affecting speleogenesis could be related to human intervention when transforming it into a show cave, which happened immediately after its discovery. Within the cave there are sediment pouches, the shallow part of which (to a least depth of $5 \mathrm{~m}$ from the interior surface) is formed of a dark reddish-brown clay alternating with thin layers of ash (Fig. 3b), deposited by humans (Papathanassopoulos, 2011). This clayey formation is underlain by an unknown sedimentary sequence down to the limestone bedrock. Research on the cave sediments is limited and is presently confined to chemical (Boyd, 2015) and human (Karkanas, 2016) superficial sediment deposition. Questions related to the deposition and depth of clay sediment and the morphology of the underlying bedrock remain open.

The geophysical investigation presented in this paper attempts to address the questions related to the clay deposition and the buried bedrock morphology, providing new information for the interpretation of cave evolution.

\section{SEISMIC TOMOGRAPHY SURVEY}

Alepotrypa Cave has large surfaces of clay deposits (exceeding $2000 \mathrm{~m}^{2}$ ) in the Entrance and Main Chambers (Fig. 2). The question we attempt to answer is to estimate the total thickness and volume of clay deposits in the Entrance Chamber, and image the sediment stratigraphy and the buried bedrock morphology. We address the above question with use of seismic traveltime tomography. 


\section{Seismic tomography}

Seismic tomography aims at reconstructing the internal characteristics of a medium by exploiting the seismic energy that has traveled through it, from a set of seismic source-receiver pairs that encloses the medium. The reconstruction is made by the tomographic inversion of the measured traveltimes obtained from the set of source-receiver pairs to produce detailed maps of seismic velocity of the medium's interior. The inversion process iteratively updates an initial velocity model, defined by data analysis and geological information, after comparison of the measured traveltimes with those calculated from the model. The region between source and receiver positions is divided into cells and modifications of the initial model that minimize the differences between calculated and observed traveltimes are sought in every iteration. The inversion result is the velocity pattern that minimizes the total differences, typically root-mean-square, between calculated and measured traveltimes (e.g., Tien-when \& Inderwiesen, 1994; Nolet, 2008).

Tomographic studies correlate P-wave velocity (derived from inversion of first-arrival traveltimes) to the bulk material quality and subsequently to the degree of weathering and fracturing of a rock mass (Barton, 2007). Velocity decreases significantly in fractured and weathered rocks and unconsolidated sediments in contrast to consolidated sediments and intact rocks (Jongmans \& Garambois, 2007). As a result, vertical and lateral changes of velocity can discriminate the overlying sediment cover from the hard rock substratum (Lanz et al., 1998; Polymenakos
\& Papamarinopoulos, 2007; Samyn et al., 2012) and highlight the alternation of steeply dipping fracture areas and rocks (Heincke et al., 2006).

In this study, we invert first-arrival traveltimes to obtain P-wave velocity maps for an evaluation of the clay sediment stratigraphy, the depth to bedrock and the bedrock morphology.

\section{Data acquisition and traveltimes}

The seismic tomography imaging at Alepotrypa Cave was made in 2014 (Polymenakos, 2014) in an area extending to about $1200 \mathrm{~m}^{2}$ in the Entrance Chamber, where an excavation pit is also located (Fig. 4). The survey area extends to the rock walls of the cave and is covered by clayey soil. Surface elevation ranges from about 12 to $19 \mathrm{~m}$ above sea level, with the highest slope to the east, a lower slope to the west and the lowest slope to the north and south.

The tomographic layout consisted of 12 receivers and 60 sources. Receivers were located along the west side of the survey area, near the entrance of the cave. Receivers were not placed in the east side of the survey area, because of surface obstructions that precluded a receiver separation adequate for the scope of the tomographic survey. Sources were positioned throughout the survey area, to overcome the limitations of receiver placement and provide sufficient ray coverage of the entire survey area. Source and receiver locations were separated by 2 to $5 \mathrm{~m}$ and arranged to achieve an average spatial coverage of $1 \mathrm{~m}$ (corresponding to an average angular coverage of $\left.5^{\circ}\right)$, sufficient for resolving geological features related to cave speleogenesis, while keeping the field logistics

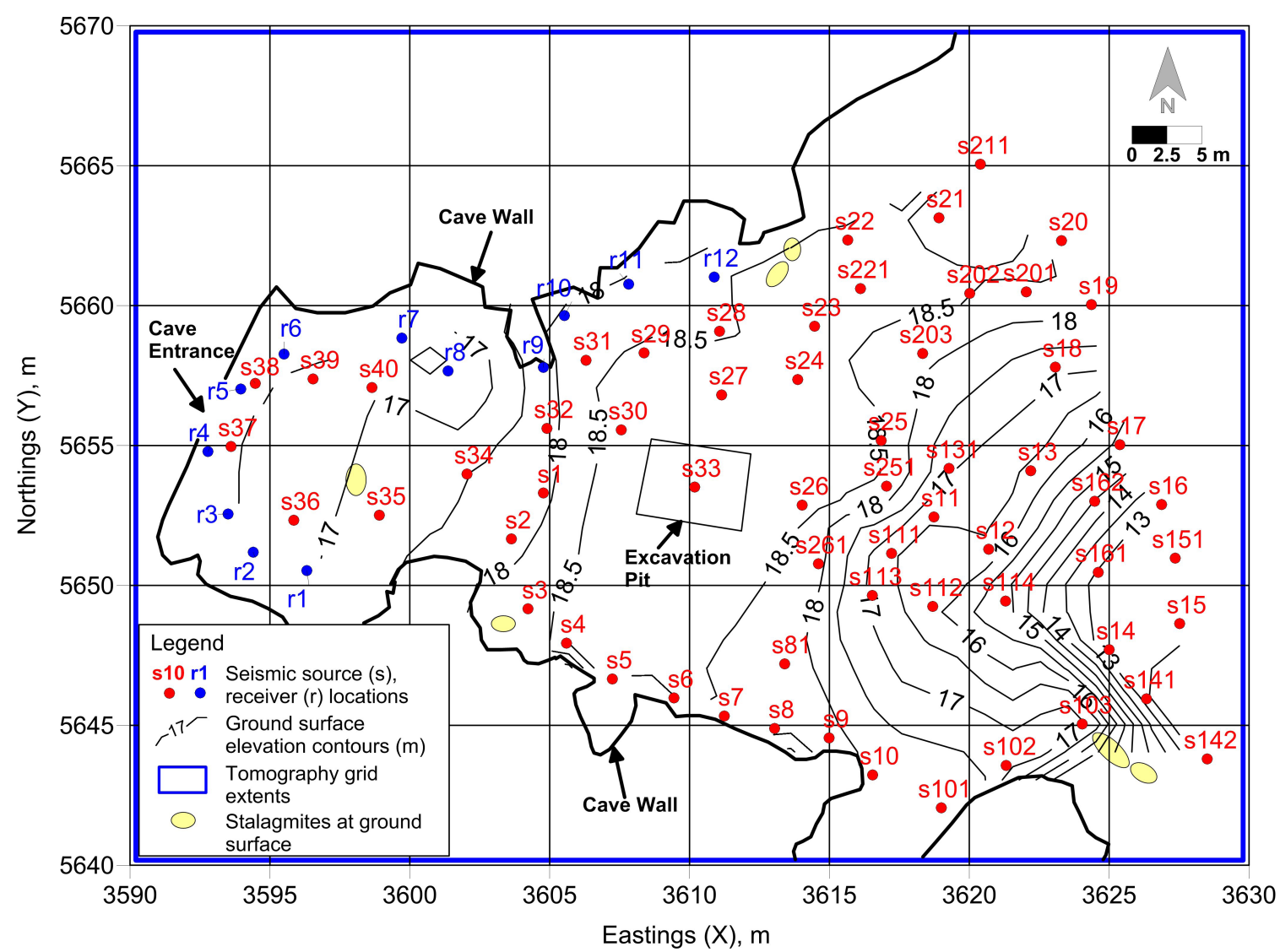

Fig. 4. The tomography survey area in the Entrance Chamber of Alepotrypa Cave. The tomography field layout and elevations (in meters above sea level) are shown. Coordinates are local easting/northing topographic coordinates. 
at a reasonable level. Source locations extended over the maximum possible elevation difference, necessary to reach the largest possible exploration depth. In addition, sources were located so as to avoid damage to stalagmites and other important surface features. The elevation difference across the survey area (about $7 \mathrm{~m}$ in the E-W direction) allowed investigation of traveltime variations as a function of depth. This provided for a quasi-3D imaging of sedimentary structure and the bedrock morphology. The positions of receivers and sources were measured with centimeter precision in the XYZ coordinates with digital surveying instruments. The source was a $2 \mathrm{~kg}$ sledgehammer, hitting on a plate made of synthetic material (acetal) that provided improved ground coupling, high-frequency energy transmission, and portability, with less weight. The receivers were 10 $\mathrm{Hz}$ vertical geophones, positioned on metal bases for better coupling with variant ground surface conditions (firm soil, concrete) and avoid drilling in the delicate cave environment. Data were recorded with a 12 channel Geometrics seismograph, using a sampling window of $192 \mathrm{~ms}$ and a sampling rate of $0.125 \mathrm{~ms}$. Stacking and appropriate filters were used for signal enhancement. A total of 720 high quality wave records were acquired.

First arrival picking was made with TomTime software (Tweeton, 2016), taking into consideration the waveform characteristics, the specific source/ receiver distance and the estimated average velocity. Representative seismic recordings with time picks are shown in Fig. 5a. Frequency spectra are shown in Fig. 5b (dominant frequencies range from 70 to $300 \mathrm{~Hz}$ ). The typical error in time picking is estimated at $1 \mathrm{~ms}$. Times and straight-ray velocities versus source-receiver distances are shown in Fig. 5c. Traveltimes range from 1 to $33 \mathrm{~ms}$. The time range widens with increasing distance, indicating that the raypaths sample the bedrock and a sediment cover with significant differences in consolidation and/or lithology. Straight-ray velocities range from 400 to $2500 \mathrm{~m} / \mathrm{s}$ and increase with raypath length indicating that a greater fraction of the raypath was in the more competent materials at depth where the attenuation
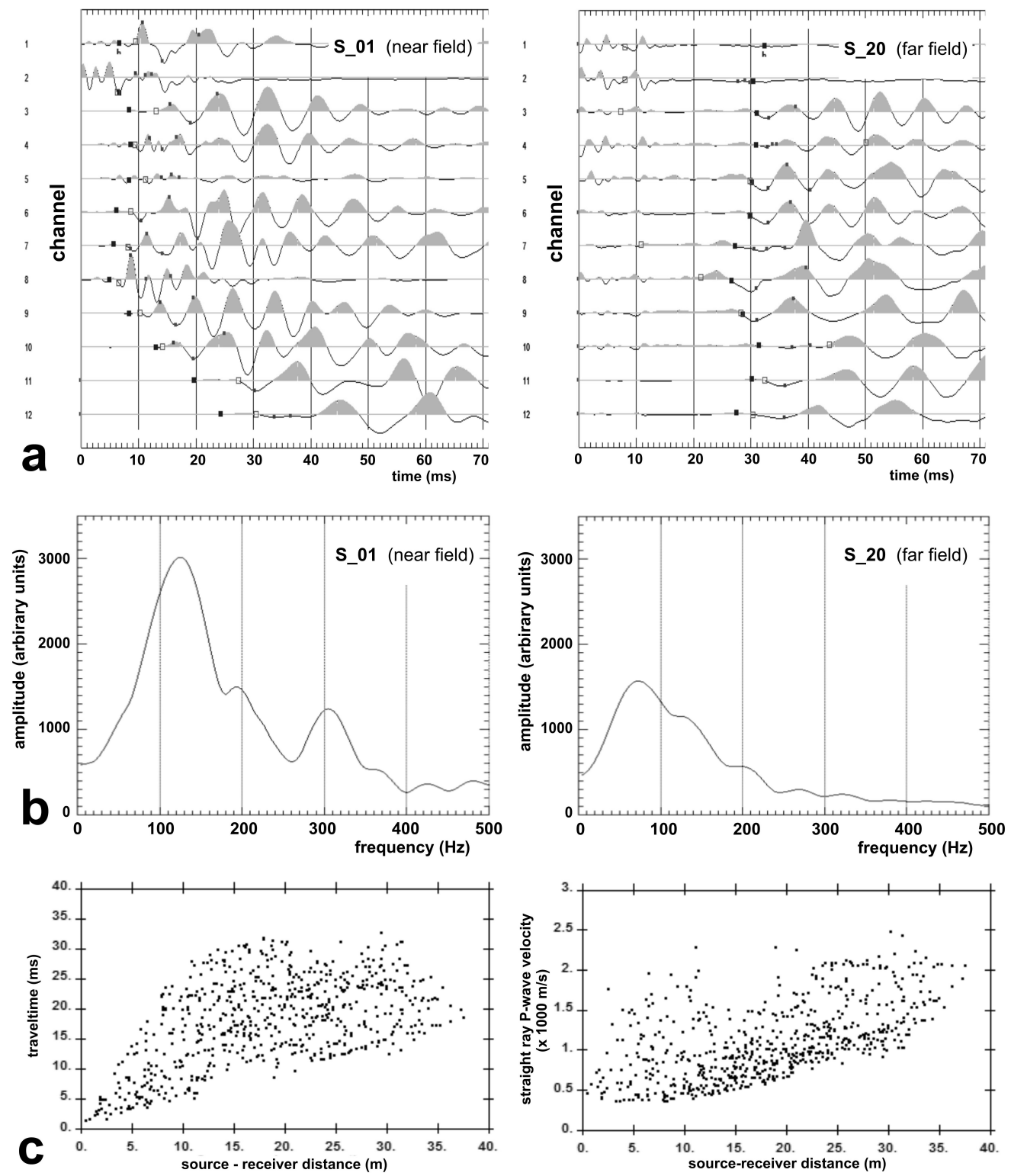

Fig. 5. Tomographic data. a) Seismic waveforms with picks of first arrival times for a near field (left) and far field (right) seismic source. Solid dots indicate time picks. Source labels refer to locations in Fig. 4; b) Fourier frequency spectra of the near and far field source records of Fig.5a; c) Time-distance plot (left) and straight-ray velocity-distance plot (right) of the tomography dataset. 
was smaller. Higher velocities at short distances indicate the influence of shallow bedrock. Based on recent observations on the actual detection ability of seismic traveltime tomography (e.g., Li \& Duric, 2013; Polymenakos \& Tweeton, 2015), the average resolution is estimated to be better than $2 \mathrm{~m}(1.1 \mathrm{~m})$, or less than $25 \%$ of the Fresnel zone width $(7.5 \mathrm{~m})$ calculated for the highest dominant frequency $(300 \mathrm{~Hz})$, an average source-receiver distance of $18 \mathrm{~m}$ and an average straight line velocity of $930 \mathrm{~m} / \mathrm{s}$.

\section{Data inversion}

First arrival times were inverted into a three-dimensional distribution of P-wave velocity, from which interpretations related to subsurface lithology and bedrock morphology were made. Traveltime inversion was performed with the SIRT algorithm (Dines \& Lytle, 1979) using GeoTomCG software (Tweeton, 2015), that allows both straight and curved raypath calculation in two or three dimensions and can obtain the most stable results and smoother images which are not critically deteriorated by noise, in contrast to other algorithms (Lehmann, 2007).

After initial testing and removal of traveltime outliers, 645 traveltimes were available for tomographic inversion. Inversion was performed on an initial model designed with a three-dimensional rectangular grid having cell dimensions of $2 \mathrm{~m}$ in either direction, approximately the smallest source-to-source and receiver-to-receiver separation, allowing for adequate ray coverage of the grid cells. Based on the tomography data, velocities in the initial model range from 330 to $2600 \mathrm{~m} / \mathrm{s}$, increasing gradually towards lower elevations. Tests with straight and curved rays resulted in a final inversion with curved ray iterations allowing $\mathrm{P}$-wave velocity to range between 300 and $3500 \mathrm{~m} / \mathrm{s}$. The most physically realistic result with fewer velocity artifacts was after 5 curved ray iterations with RMS residual of $2.4 \mathrm{~ms}$. Tests with different starting models and increased number of iterations showed that an improvement of the RMS residual did not lead to better imaging but only increased velocity smearing and unrealistic velocity contrasts (artifacts). Fig. 6a shows the good overall convergence between observed and calculated traveltimes. Fig. 6b shows that the survey area is adequately and fully covered by calculated raypaths. Raypath coverage and trajectories reflect strong velocity contrasts between parts of the survey area, that resulted in relatively lower coverage and decreased detail in the velocity model at the deeper part of the eastern side of the survey area (see Fig. 8 and relevant discussion below). The placement of additional receivers that might increase ray coverage in this area was not possible due to access limitations.

\section{INTERPETATION AND DISCUSSION}

\section{P-wave velocity}

$\mathrm{P}$-wave velocities show a wide range, from 400 to 3000 m/s (Fig. 7a, c). As elevation decreases, higher velocities gradually prevail over larger parts of the survey area. Considering the velocity variations, two primary limits can be set, at $1000 \mathrm{~m} / \mathrm{s}$ and $1900 \mathrm{~m} / \mathrm{s}$ respectively. These velocities separate areas with low velocity gradient (Fig. 7b, 7c). The higher primary velocity limit is interpreted as separating two major lithological formations, that of the sediments (velocity range $400-1900 \mathrm{~m} / \mathrm{s}$ ) and the rocky bedrock (velocity range $1900-3000 \mathrm{~m} / \mathrm{s})$. The lower velocity range corresponds to soil material with variable stiffness, 

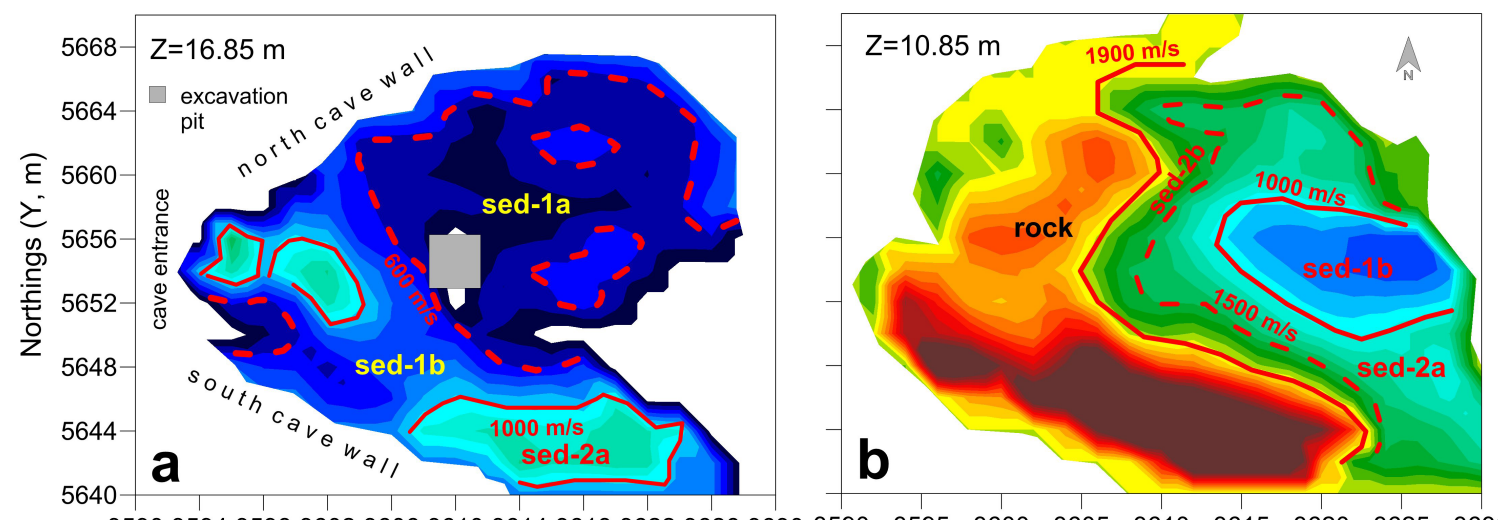

$359035943598360236063610361436183622362636303590 \quad 3595 \quad 3600 \quad 3605 \quad 3610 \quad 3615 \quad 3620 \quad 3625 \quad 3630$

Eastings $(\mathrm{X}, \mathrm{m})$
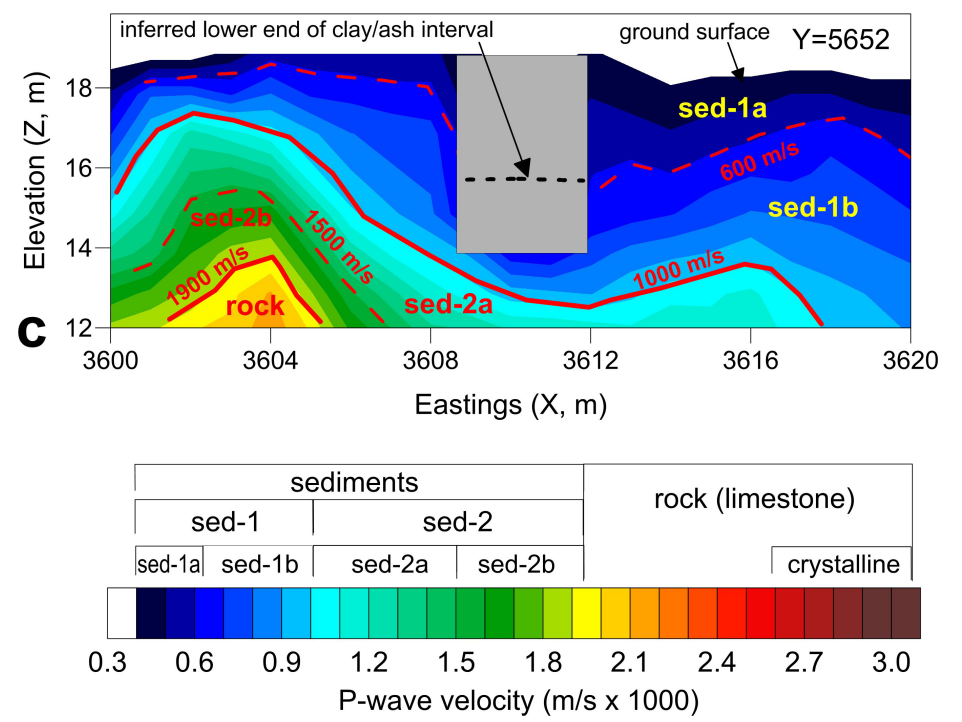

Fig. 7. Interpreted velocities. a) and b) Horizontal velocity maps resulting from inversion of traveltime data, with velocity limits emphasizing possible lateral variations within the sedimentary pack at higher elevations (a), and between the sedimentary pack and the rocky substrate at lower elevations b); c) Vertical velocity map emphasizing possible vertical variations through the sediments and the substrate. A relation of the velocity pattern with part of the shallow geological structure is also shown. For a detailed discussion see the $P$-wave velocity section.

whereas the higher velocity range corresponds to medium-to-hard rock with velocities typical for limestone (Schön, 2015). Values higher than 2600 $\mathrm{m} / \mathrm{s}$ are interpreted to correlate with crystalline limestone and are consistent with the lower limit of the regional velocity range estimated for the limestones and marbles of the Kriti-Mani unit (3500 to 4500 m/s; IGME, 1989). The velocity pattern shows no effect of groundwater, suggesting its absence (or, very limited presence) within the depths explored with tomography. The lower primary velocity limit is interpreted as separating sediments of different stiffness that could be related to different lithology: velocities up to 1000 $\mathrm{m} / \mathrm{s}$ correspond to a low stiffness soil unit (sed-1), while values in the range $1000-1900 \mathrm{~m} / \mathrm{s}$ suggest a stiff soil unit (sed-2), with the higher values (1300$1900 \mathrm{~m} / \mathrm{s}$ ) being typical for very stiff clay sediments (Schön, 2015). A further differentiation can be implied by setting a secondary low-velocity limit at $600 \mathrm{~m} / \mathrm{s}$, separating the sed-1 unit into two sub-units which show low velocity gradient (sed-1a, sed-1b; Fig. 7a). Likewise, a high-velocity secondary limit can be set at $1500 \mathrm{~m} / \mathrm{s}$, separating the sed-2 unit into sed-2a and sed-2b sub-units (Fig. $7 b$ ).

From a comparison of the vertical velocity pattern with the sedimentary sequence in the excavation pit (Fig. 7c), the $600 \mathrm{~m} / \mathrm{s}$ sub-limit corresponds approximately to a transition from the superficial finegrained clay/ash interval to the underlying sediments. This correspondence is tentative, since excavation data are not conclusive and the depth span of the excavated sediments is quite shorter than that explored with seismic tomography. It indicates, however, a relation to lithological changes. P-wave velocity is primarily related to the stiffness/strength of geological materials which is affected by parameters such as porosity/ fracture density, saturation/groundwater, and grain size (Barton, 2007), that are closely related to lithology. Karstification and weathering of the bedrock surface may affect P-wave velocity at the sedimentbedrock interface, however at a much lesser degree than lithological changes (e.g., Hamdan et al., 2012; Schmelzbach et al., 2015). Furthermore, tomographic P-wave velocity models have been proved capable of reconstructing sharp lithological boundaries better than other velocity models obtained with refraction, surface waves, etc. (e.g., Barton, 2007; Gance et al., 2012). Thus, we assume that the above velocity limits relate accurately to major lithological changes and provide us with a means to follow possible lithological variations throughout the survey area, as discussed below. 


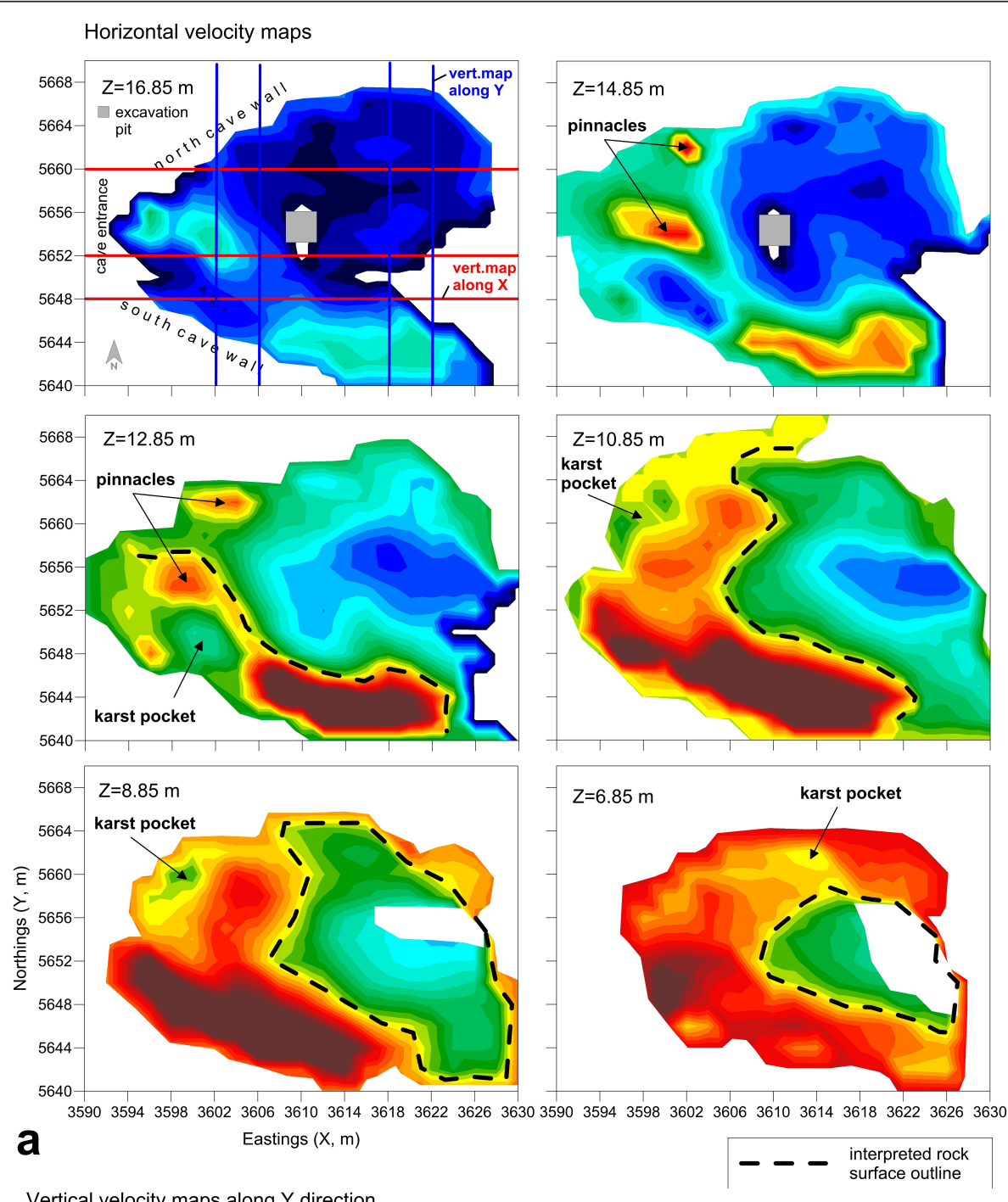

Vertical velocity maps along $Y$ direction
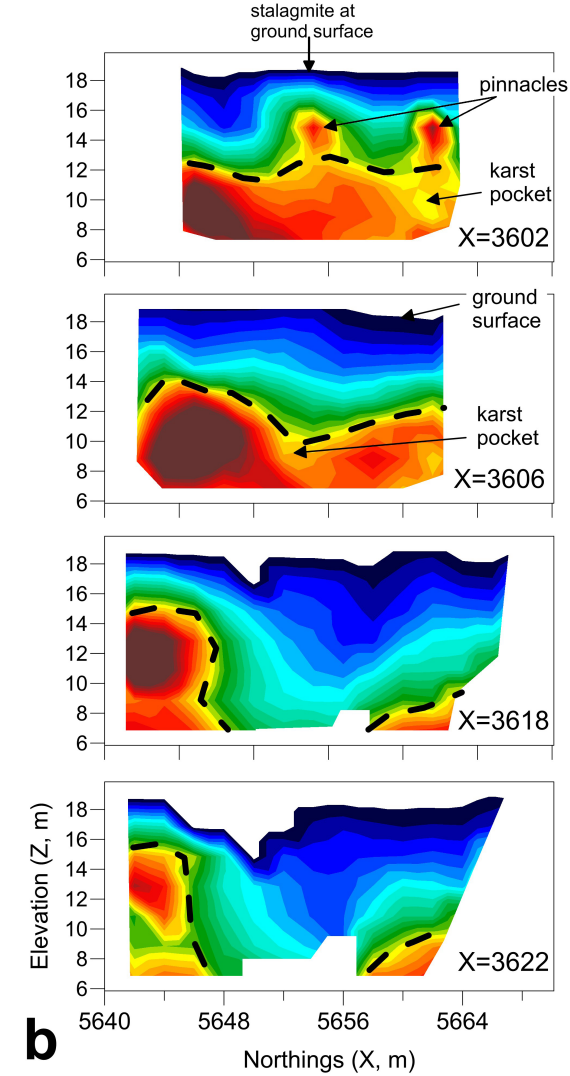

Vertical velocity maps along $X$ direction
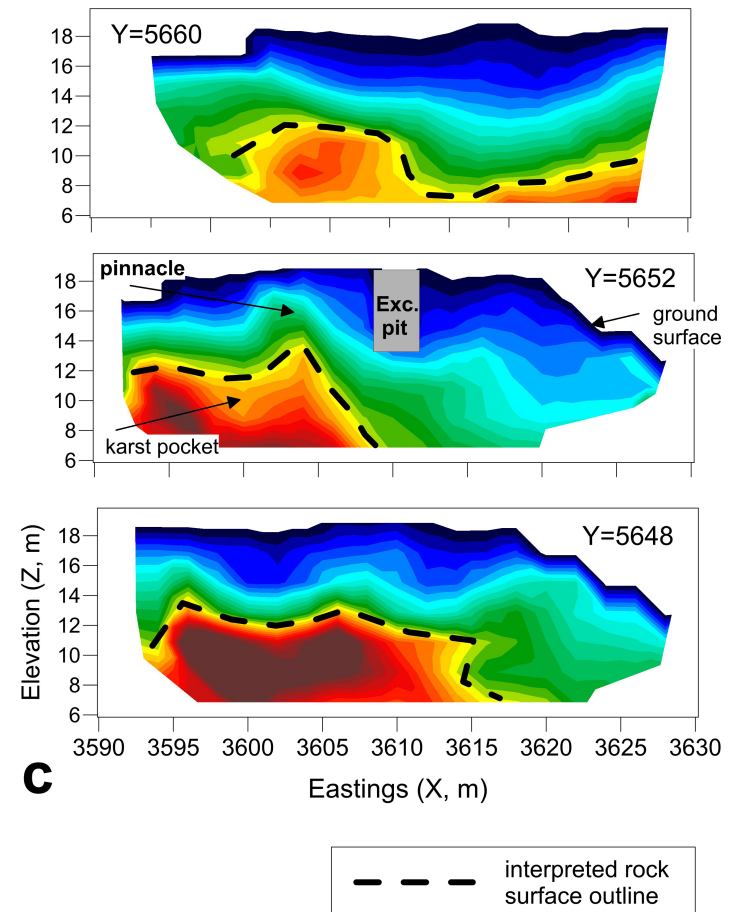

Fig. 8. Velocity maps resulting from traveltime inversion. a) Horizontal maps; b) Vertical maps along $Y$ direction, i.e. across the cave; c) Vertical maps along $X$ direction, i.e. along the cave. The $X$ or $Y$ location of each map is shown on the map. Graphical locations of vertical maps are shown in $Z=16.85$ (Fig. 8a, top left). Color scale as in Fig. 7. 


\section{Morphology of buried rock surface}

A sequence of horizontal velocity maps (Fig. 8a) shows that the bedrock gradually abounds in the survey area with decreasing elevation, with the shallowest end in the western, northern and southwestern part and the deepest end in the eastern part. Examination of vertical velocity maps (Fig. 8b, $8 c)$ allows us to visualize the original cross-section shape of the buried karstic conduit in the Entrance Chamber. Vertical maps across the cave (Fig. 8b) show that the conduit floor, from shallow and rough in the west, becomes narrow at its edges and deep in the center, describing a smooth but irregular $\mathrm{V}$ shape in the east, with a steeper southern slope and a gentler north slope. Vertical maps along the cave (Fig. 8c) show a considerable elevation drop of the conduit floor in the central and eastern part of the cave. The lowest bedrock elevation is estimated at 6.0$6.5 \mathrm{~m}$ near the eastern end of the survey area (Fig. 8b; map at $X=3622$, Fig. 8c; map at $Y=5652$ ). Decreased ray coverage did not allow a detailed imaging of the sediment-bedrock interface in the deepest eastern part of the model (Fig.8a; central eastern part of maps at $Z=8.85$ and 6.85 , Fig. $8 \mathrm{~b}$ and $8 \mathrm{c}$; central bottom parts of maps at $X=3618$ and 3622, and lower right parts of maps at $Y=5648$ and 5652). The isolated highvelocity features at higher elevations in the western part of the survey area (Fig. 8a; maps at $Z=14.85$ and 12.85), have the form of relief-relics, or pinnacles, of the bedrock when seen on vertical velocity maps (Fig. 8b; map at $X=3602$, Fig. 8c; map at $Y=5652)$. These features are interpreted as bases of large stalagmites on the bedrock surface. One such stalagmite, actually present on the ground surface at location $\mathrm{X}=3598$, $\mathrm{Y}=5654$ (Fig. 4), corresponds to the larger high velocity anomaly seen in the horizontal velocity maps at $Z=14.85$ and $12.85 \mathrm{~m}$. Indications of possible locally increased karstification in the bedrock (karst pockets) may be expressed through locally reduced values in the interpreted rock velocity range, in particular in the $1900-2200 \mathrm{~m} / \mathrm{s}$ range (Fig. 8a; maps at $Z=12.85$ to 6.85, Fig. 8b; maps at $X=3602$ and 3606; Fig. 8c; map at $\mathrm{Y}=5652)$.

The bedrock morphology is reconstructed in detail by the bedrock surface calculated from the interpreted horizontal velocity maps (Fig. 9). The buried rock surface follows a distinctive, semi-circular shape, with the concave side oriented to the east-northeast (Fig. 9a). This funnel-like shape of the bedrock surface implies principally a karstic origin, possibly related to a sinkhole. However, the elevation drop, being larger on the south flank than on the north flank of the bedrock surface, suggests that the southern flank could have been shaped by the influence of a possible rock fracture running WNW-ESE (Fig. 9b). The calculated bedrock surface emphasizes the elevation differences across the survey area and the abundance of relief-relics (Fig. 9b).

\section{Sediment deposition, thickness, and volume}

Considering the main differentiation within the sediments delineated by the $1000 \mathrm{~m} / \mathrm{s}$ value, the upper less stiff material (sed-1) covers much of the survey area at the highest elevation (Fig. 8a; map at $Z=16.85$ ), while it is confined to the central and eastern part at lower elevations until entirely replaced by the stiffer material (sed-2) below $Z=8$. As suggested by the vertical velocity maps (Fig. $8 \mathrm{~b}$ and $8 c)$, the deposition of sed-1 and sed-2 units follows the underlying bedrock morphology. However, significant differentiations appear in the deposition of the lower (sed-2) unit, as suggested by local increase in depth (Fig. 8b; maps at $X=3618$ and 3622, Fig. 8c; maps at $\mathrm{Y}=5648$ and 5652).

The interfaces of interpreted sedimentary units were used for estimating their thicknesses. For the total sedimentary pack, thickness ranges from 2 up to and $12 \mathrm{~m}$, increasing towards the eastern part of the survey area where it reaches its maximum, eastward of the excavation pit (Fig. 10a). A similar depositional pattern is suggested for the upper (sed1) and the topmost soil units (sed-1a, interpreted as corresponding to the clay/ash interval), with thicknesses ranging from 0.5 to $9 \mathrm{~m}$ and from 0.2 $\mathrm{m}$ to $4 \mathrm{~m}$, respectively, reaching their maxima in the eastern part of the survey area (Fig. 10b and 10c). The thicknesses of sediment units are considerably larger in the center than on the sides of the survey
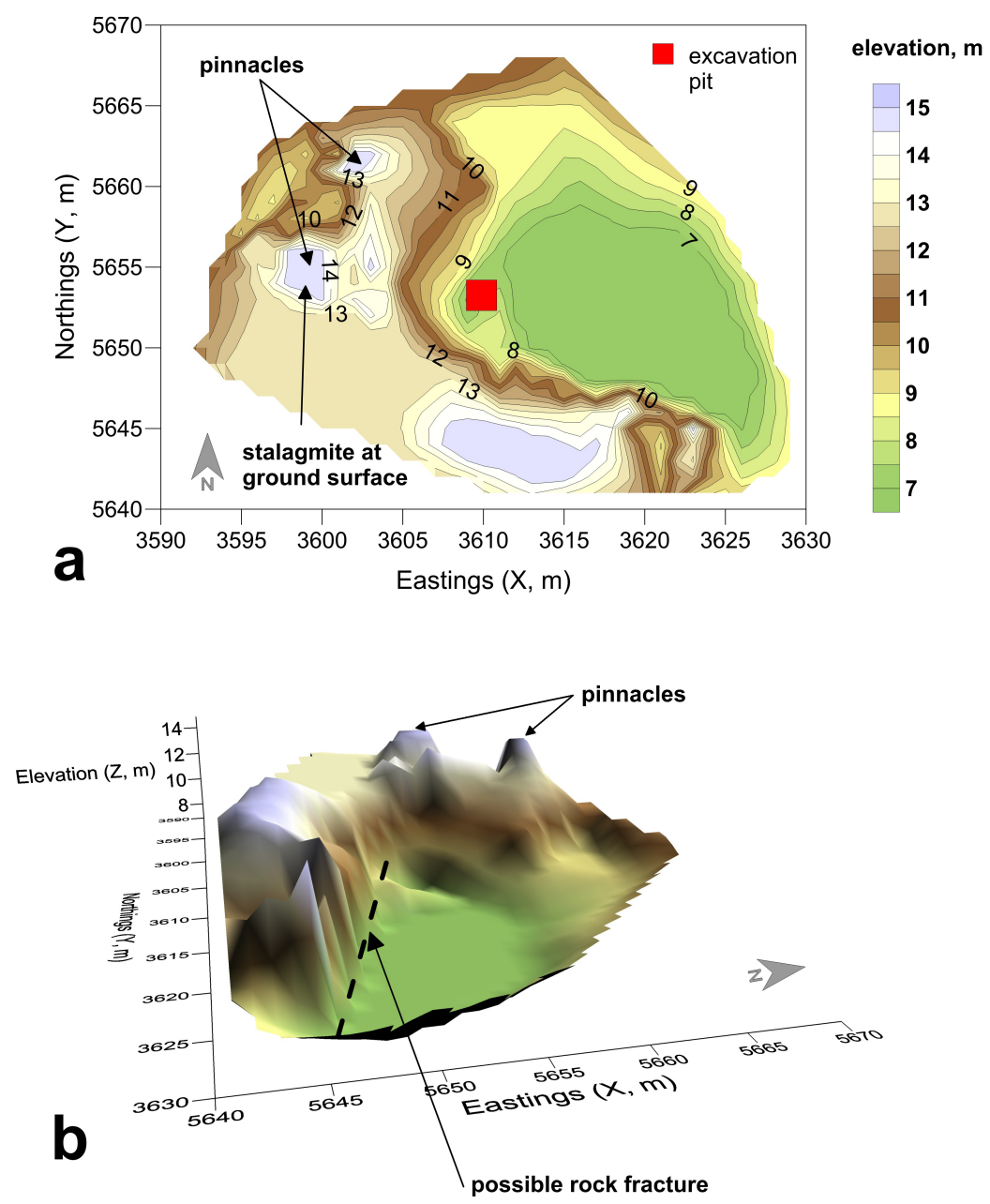

Fig. 9. Bedrock surface, calculated from interpreted velocity maps, expressed as elevation (in meters, above sea level). a) Contour plot; b) 3D surface plot; lighting source at 109 degrees horizontal angle, 56 degrees vertical angle; shininess $80 \%$. 


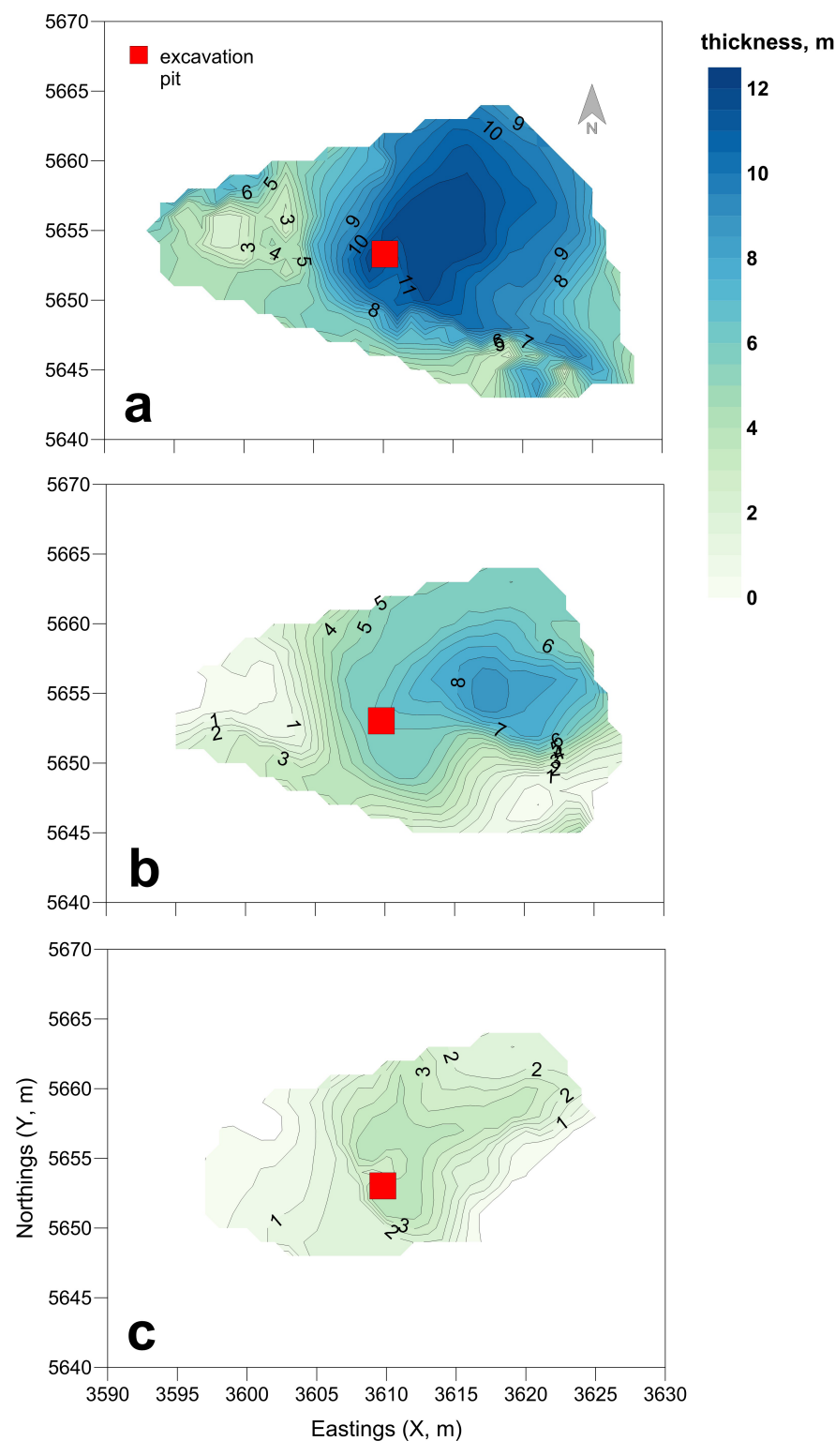

Fig. 10. Sediment thicknesses calculated from interpretation of horizontal velocity sections. a) Total sediment pack (sed-1 + sed-2); b) Upper sediment unit (sed-1); c) Topmost sediment unit (sed-1a).

area. This suggests that the sediment deposition in the Entrance Chamber is related to the original shape of the buried karstic conduit. On the other hand, the areas with a total thickness of less than $2 \mathrm{~m}$ in the western edge of the survey area may relate to clay evacuation areas due to depositional dynamics (c.f. Nehme et al., 2013). However, human intervention may also be an important factor in the discharging of clay volume.

The interpreted sediment and bedrock surfaces combined with the ground surface allowed us to calculate the volume of the main sediment units with use of the Simpsons's rule provided with Surfer software (Golden Software, 2011), applied on a 1x1 $\mathrm{m}$ grid. This amounts to about $4000 \mathrm{~m}^{3}$ for the total sediment pack, about $2000 \mathrm{~m}^{3}$ for the upper (sed-1) unit and $900 \mathrm{~m}^{3}$ for the topmost (sed-1a) unit related to the clay/ash interval.

Calculated thicknesses and volumes are accurate within the limits of spatial coverage and resolution of the tomographic experiment, taking into account possible local effects of factors other than lithology on P-wave velocity, and effects on the detail of the velocity model due to reduced ray coverage; as with all geophysical methods, use of independent information (geophysical, geological, etc.), if available, may constrain traveltime inversion and reduce possible uncertainties. Nevertheless, the information on sediment thicknesses and volumes can be significant for studying speleogenesis when expanded to the total volume of sediments in all chambers of Alepotrypa Cave.

\section{CONCLUSIONS}

The seismic tomography imaging of Alepotrypa Cave succeeded in mapping the bedrock surface and revealing the shape of the original conduit of the cave, currently covered with up to $12 \mathrm{~m}$ of clay sediments. Relief-relics (pinnacles; bases of large stalagmites) and possible tectonic influences in the shaping of cave buried morphology were inferred from variations of the bedrock surface. The sediments overlying the bedrock amount to a total volume of $4000 \mathrm{~m}^{3}$ and show significant differentiations in stiffness that may be also related to differing lithology.

Our results show that seismic tomography can be a very effective exploration tool in the interior of a cave, for mapping the bedrock underlying the surface sediments and large-scale lithological and stiffness variations within the sediments. The method can also be used for mapping the shallow underwater cave chambers and non-destructively assessing rock quality in caves to serve in rock stabilization studies.

\section{ACKNOWLEDGEMENTS}

The author wishes to acknowledge the Director of the Diros Project Dr. Giorgos Papathanassopoulos (Honorary Director of Antiquities) and CoDirectors Dr. Anastasia Papathanasiou (Ephorate of Paleoanthropology and Speleology of Southern Greece), William Parkinson (American Field Museum), and Michael Galaty (Mississippi State University), for supporting the tomography survey at Alepotrypa Cave. The Diros Project is conducted through the Directorate of Paleoanthropology and Speleology of Southern Greece, and financially supported by the Wenner-Gren Foundation for Anthropological Research, the Institute for Aegean Prehistory, the Leon-Levy Foundation, and the Archaeological Institute for America-Cotsen Excavation Grant.

Ms. Danielle Riebe (University of Illinois at Chicago) and Ms. Rebecca Seifried (University of Illinois at Chicago) are acknowledged for the topographical work at the tomography site. Mr. Apostolis Giagakis is acknowledged for his assistance in fieldwork.

\section{REFERENCES}

Adamczyk A., Malinowski M. \& Malehmir A., 2013 Application of first-arrival tomography to characterize a quick clay landslide site in Southwest Sweden. Acta Geophysica, 61 (5): 1057-1073.

http://dx.doi.org/10.2478/s11600-013-0136-y 
Ajo-Franklin J.B., Peterson J., Doetsch J. \& Daley T.M., 2013 - High-resolution characterization of a $\mathrm{CO}_{2}$ plume using crosswell seismic tomography: Cranfield, MS, USA. International Journal of Greenhouse Gas Control, 18: 497-509. http://dx.doi.org/10.1016/j.ijggc.2012.12.018

Barton N., 2007 - Rock Quality, Seismic Velocity, Attenuation and Anisotropy. Taylor \& Francis Group, London, $729 \mathrm{p}$.

Bassiakos I., 1993 - Dating of cave fossils and speleothems with the ESR method and study of subterranean karst morphology and relevant radiometric and geological conditions in speleo-environments of Diros, Mani area. Unpublished $\mathrm{PhD}$ Thesis, Department of Geology, University of Athens, 380 p. (in Greek).

Boyd M., 2015 - Speleothems from warm climates holocene records from the Caribbean and Mediterranean Regions. Unpublished $\mathrm{PhD}$ Thesis. Department of Physical Geography, Stockholm University, 82 p.

Chamberlain A., Sellers W., Proctor C. \& Coard R., 2000 - Cave detection in limestone using Ground Penetrating Radar. Journal of Archaeological Science, 27 (10): 957-964. http://dx.doi.org/10.1006/jasc.1999.0525

Chalikakis K., Plagnes V., Guerin R., Valois R. \& Bosch F.P., 2011 - Contribution of geophysical methods to karst-system exploration: an overview. Hydrogeology Journal, 19: 1169-1180.

http://dx.doi.org/10.1007/s10040-011-0746-x

Coulouma G., Samyn K., Grandjean G., Follain S. \& Lagacherie P., 2012. Combining seismic and electric methods for predicting bedrock depth along a Mediterranean soil toposequence. Geoderma, 170: 39-47. http://dx.doi.org/10.1016/j.geoderma.2011.11.015

Dines K. \& Lytle J., 1979 - Computerized geophysical tomography. Proceedings of Institute of Electrical and Electronics Engineers (IEEE), 67 (7): 1065-1073. http://dx.doi.org/10.1109/PROC.1979.11390

Drahor M.G., Kurtulmus T.O., Berge M.A., Hartmann M. \& Speidel M.A., 2008 - Magnetic imaging and electrical resistivity tomography studies in a Roman military installation found in Satala archaeological site, northeastern Anatolia, Turkey. Journal of Archaeological Science, 35 (2): 259-271. http://dx.doi.org/10.1016/j.jas.2007.02.026

El-Qady G., Hafez M., Abdalla M.A. \& Ushijima K., 2005 - Imaging subsurface cavities using geoelectric tomography and ground-penetrating radar. Journal of Cave and Karst Studies, 67: 174-181.

Farrant A.R. \& Smart P.L., 2011 - Role of sediment in speleogenesis; sedimentation and paragenesis. Geomorphology, 134 (1-2): 79-93. http://dx.doi.org/10.1016/j.geomorph.2011.06.006

Ford D.C. \& Ewers R.O., 1978 - The development of limestone cave systems in the dimensions of length and depth. Canadian Journal of Earth Science, 15 (11): 1783-1798. http://dx.doi.org/10.1139/e78-186

Gance J., Grandjean G., Samyn K. \& Malet J-P., 2012 - Quasi-Newton inversion of seismic first arrivals using source finite bandwidth assumption: Application to subsurface characterization of landslides. Journal of Applied Geophysics, 87: 94-106.

http://dx.doi.org/10.1016/j.jappgeo.2012.09.008

Giannopoulos B., 2000 - Contribution to the study of the present and past environments of the most significant Greek caves. Unpublished PhD thesis, Department of Geology, University of Athens, 436 p. (in Greek)

Gibson P.J., Lyle P. \& George P., 2004 - Application of resistivity and magnetometry geophysical techniques for near-surface investigations in karstic terranes in Ireland. Journal of Cave and Karst Studies, 66: 35-38.
Giocoli A., Stabile T.A., Adurno I., Perrone A., Gallipoli M. R., Gueguen E., Norelli E. \& Piscitelli S., 2015 Geological and geophysical characterization of the southeastern side of the High Agri Valley (southern Apennines, Italy). Natural Hazards and Earth Systems Sciences, 15: 315-323.

http://dx.doi.org/10.5194/nhess-15-315-2015

Golden Software, 2011 - Surfer 11, Surface Mapping System. Golden, Colorado.

Gosar A. \& Čeru, T., 2016 - Search for an artificially buried karst cave entrance using ground penetrating radar: a successful case of locating the $S$-19 Cave in the Mt. Kanin massif (NW Slovenia). International Journal of Speleology, 45 (2): 135-147.

http://dx.doi.org/10.5038/1827-806X.45.2.1979

Griffiths D.H. \& Barker R.D., 1994 - Electrical imaging in archaeology. Journal of Archaeological Science, 21 (2): 153-158 http://dx.doi.org/10.1006/jasc.1994.1017

Hamdan H., Economou N., Kritikakis G., Andronikidis N., Manoutsoglou E., Vafidis A., Pangratis P. \& Apostolidou G., $2012-2 D$ and $3 D$ imaging of the metamorphic carbonates at Omalos plateau/polje, Crete, Greece by employing independent and joint inversion on resistivity and seismic data. International Jourmal of Speleology, 41 (2): 199-209.

http://dx.doi.org/10.5038/1827-806X.41.2.7

Harvitch F. \& Valenta J., 2011 - The identification of faults using morphostructural and geophysical methods: a case study from Strasin cave site. Acta geodynamica et geomaterialia, 8: 425-441.

Heincke B., Maurer H., Green A.G., Willenberg H., Spillmann T. \& Burlini, L., 2006 - Characterizing an unstable mountain slope using shallow $2 D$ and $3 D$ seismic tomography. Geophysics, 71 (6): B241-B256. http://dx.doi.org/10.1190/1.2338823

Ibs-von Seht M. \& Wohlenberg J., 1999 - Microtremor measurements used to map thickness of soft sediments. Bulletin of the Seismological Society of America, 89: $250-259$.

IGME, 1989 - Seismotectonic map of Greece. Scale 1:500.000, Institute of Geological and Mineral Research, Athens.

Jackson M.J., Friedel M.J., Tweeton D.R., Scott D.F. \& Williams T.J., 1995 - Three-dimensional imaging of underground mine structures using seismic tomography. Proceedings of the Symposium for the Application of Geophysics in Engineering and Environmental Problems (SAGEEP) '95 (Orlando, Florida, Apr. 1995): 221-230. http://dx.doi.org/10.4133/1.2922140

Jessop J.A., Hauser K.L. \& Gese D.D., 1995 - Evaluation of geophysical methods for locating subsurface hazards in the Shawnee National Forest. Conference on the Environment and Safety, Colorado Springs CO, April 24-28, 1995, Abstract Book: 26.

Jongmans D. \& Garambois S., 2007 - Geophysical investigation of landslides: a review. Bulletin Societe Geologique Francaise, 178: 101-112.

http://dx.doi.org/10.2113/gssgfbull.178.2.101

Karkanas P., 2016 - Microstratigraphic Study of the Neolithic Alepotrypa Cave, Mani, Greece. Abstract, $81^{\text {st }}$ Annual Meeting of the Society for American Archaeology, Orlando, Florida.

http://www.saa.org/Portals/0/SAA/MEETINGS/ 2016\%20Abstracts/I L.pdf [Accessed: May 6, 2016].

Kauffman O., 2002 - Rapport de synthèse de la prospection géophysique réalisée dans la salle Plane de l'Aven d'Orgnac. Rapport interne, Université de Savoie, EDYTEM, 12 p. 
Lanz E., Maurer H. \& Green, A.G., 1998 - Refraction tomography over a buried waste disposal site. Geophysics, 63 (4): 1414-1433. http://dx.doi.org/10.1190/1.1444443

Lehmann B., 2007 - Seismic traveltime tomography for engineering and exploration applications. EAGE Publications, DB Houten, $273 \mathrm{p}$.

Li C. \& Duric N., 2013 - Resolution limitation of travel time tomography: beyond the first Fresnel zone. In: Bosch J.G. \& Doyley M.M. (Eds.), Medical Imaging 2013: Ultrasonic Imaging, Tomography, and Therapy. Proceedings of the Society of Photographic Instrumentation Engineers (SPIE), 8675: 86751D.

http://dx.doi.org/10.1117/12.2006978(86751D)

Nehmé C., Voisin C., Mariscal A., Gérard P.C., Cornou C., Jabbour-Gédéon B., Amhaz S., Salloum N., BadaroSaliba N., Adjizian-Gerard J. \& Delannoy J.J., 2013 The use of passive seismological imaging in speleogenetic studies: an example from Kanaan Cave, Lebanon. International Journal of Speleology, 42: 97-108. http://dx.doi.org/10.5038/1827-806X.42.2.1

Nolet G., 2008 - A breviary of seismic tomography. Cambridge University Press, 360 p. http://dx.doi.org/10.1017/CBO9780511984709

Palmer A.N., 2007 - Cave geology. Cave Books, Dayton, 454 p.

Papathanasiou A., 2001 - A bioarchaeological analysis of Neolithic Alepotrypa Cave, Greece. Oxford, Archaeopress, BAR. International Series 961, 173 p.

Papathanassopoulos G.A., 1996 - Neolithic Deros: the Alepotrypa Cave. In: Papathanassopoulos G.A. (Ed.), Neolithic culture in Greece (Athens), p. 80-84. Papathanassopoulos G.A. (Ed.), 2011 - The Neolithic Diro: Alepotrypa Cave. Melissa Editions / Centre of Neolithic Studies of Diros, Athens, 231 p.

Parkinson W., Papathanasiou A., Galaty M., Pullen D. \& Papathanassopoulos G., 2016 - The Diros Project: Multidisciplinary Investigations at Alepotrypa Cave and Ksagounaki Promontory, 2010-2015. Abstract, $81^{\text {st }}$ Annual Meeting of the Society for American Archaeology, Orlando, Florida.

http://www.saa.org/Portals/0/SAA/MEETINGS/ 2016\%20Abstracts/M P R2.pdf [Accessed: May 6, 2016].

Perroux A.-S., 2005 - Les remplissages détritiques endokarstiques. Contribution méthodologique à la lecture des mémoires paléogéographiques et environnementales. Application aux systèmes karstiques de Choranche (Vercors) et d'Orgnac (Bas- Vivarais). Unpublished $\mathrm{PhD}$ Thesis, Université de Savoie, 418 p.

Petrocheilou A., 1992 - The Greek Caves. $2^{\text {nd }}$ edition, Ekdotike Athenon, Athens, 160 p.

Polymenakos L., 2014 - Geophysical investigation at Alepotrypa Cave, Diros, Lakonia, Greece. Technical Report, Athens, $31 \mathrm{p}$.

Polymenakos L. \& Papamarinopoulos S., 2005 Exploring a prehistoric site for human structures by three dimensional seismic tomography. Archaeological Prospection, 12 (4): 221-233.

http://dx.doi.org/10.1002/arp.259

Polymenakos, L. \& Papamarinopoulos S., 2007 - Using seismic traveltime tomography in geoarchaeological exploration: the case of Chatby cemeteries site in Alexandria, Egypt. Near Surface Geophysics, 5: 209-219. http://dx.doi.org/10.3997/1873-0604.2006033
Polymenakos L. \& Tweeton D., 2015 - Reevaluating a seismic traveltime tomography survey at Kastas Tumulus (Amphipolis, Greece). Journal of Archaeological Science: Reports, 4: 434-446.

http://dx.doi.org/10.1016/j.jasrep.2015.10.012

Polymenakos L., Papamarinopoulos S.P., Liossis A. \& Koukouli-Chryssanthaki C., 2004 - Investigation of a monumental Macedonian tumulus by three-dimensional seismic tomography. Archaeological Prospection, 11 (3): 145-158.

http://dx.doi.org/10.1002/arp.228

Samyn K., Travelletti J., Bitri A., Grandjean G. \& Malet J.-P, 2012 - Characterization of a landslide geometry using $3 D$ seismic refraction traveltime tomography: The La Valette landslide case history. Journal of Applied Geophysics, 86: 120-132.

http://dx.doi.org/10.1016/j.jappgeo.2012.07.014

Schön J.H., 2015 - Physical properties of rocks. Fundamentals and principles of petrophysics. $2^{\text {nd }}$ ed., Elsevier, $512 \mathrm{p}$.

Schmelzbach C., Jordi C., Sollberger D., Doetsch J., Kaufmann M., Meijer W.Y., Manukyan E., Robertsson J., Maurer H., Greenhalgh S. \& Horstmeyer H., 2015 - Understanding the impact of karst on seismic wave propagation - A multi-method geophysical study. Extended abstract, $77^{\text {th }}$ European Association of Geoscientists and Engineers (EAGE) Conference and Exhibition - Workshops (WS11).

http://dx.doi.org/10.3997/2214-4609.201413546

Surányi G., Dombrádi E. \& Szabolcs Leél-Őssy, 2010 - Contributions of geophysical techniques to the exploration of the Molnár János Cave (Budapest, Hungary). Acta Carsologica, 39: 565-576. http://dx.doi.org/10.3986/ac.v39i3.84

Tien-when L. \& Inderwiesen P., 1994 - Fundamentals of seismic tomography. Society of Exploration Geophysicists, Tulsa, $187 \mathrm{p}$.

Tomkins K., 2009 - Domesticity by default. Ritual, ritualization and cave-use in the Neolithic Aegean. Oxford Journal of Archaeology, 28: 125-153.

http://dx.doi.org/10.1111/j.1468-0092.2009.00322.x

Tweeton D.R., 2015 - GeoTomCG, Three dimensional geophysical tomography software. GeoTom LLC, Apple Valley, Minnesota, $70 \mathrm{p}$.

Tweeton D.R., 2016 - TomTime, Time and amplitude picking software. GeoTom LLC, Apple Valley, Minnesota, $53 \mathrm{p}$.

Valois R., Bermejo L., Guerin R., Hinguant S., Pigeaud R. \& Rodet J., 2010 - Karstic morphologies identified with geophysics around Saulges Caves (Mayenne, France). Archaeological Prospection, 17 (3): 151-160. http://dx.doi.org/10.1002/arp.385

Witten A.J., Levy T.E., Ursic J. \& White P., 1995 Geophysical diffraction tomography: New view on the Shiqmim Prehistoric Subterranean Village Site (Israel). Geoarchaeology, 10: 97-118. http://dx.doi.org/10.1002/gea.3340100202

Zhou W., Beck B.F. \& Stephenson J.B., 2000 - Reliability of dipole-dipole electrical resistivity tomography for defining depth to bedrock in covered karst terrains. Environmental Geology, 39 (7): 760-766. http://dx.doi.org/10.1007/s002540050491 